\title{
Accumulation and depuration kinetics of paralytic shellfish toxins in the scallop Patinopecten yessoensis fed Alexandrium tamarense
}

\author{
Katsushi Sekiguchi ${ }^{1}$, Shigeru Sato ${ }^{2}$, Takehiko Ogata ${ }^{2}$, Shinnosuke Kaga ${ }^{1}$, \\ Masaaki Kodama ${ }^{2, *}$ \\ ${ }^{1}$ Iwate Fisheries Technology Center, Kamaishi, Iwate 026-0001, Japan \\ ${ }^{2}$ School of Fisheries Sciences, Kitasato University, Sanriku, Iwate 022-0101, Japan
}

\begin{abstract}
Adult scallops, Patinopecten yessoensis, held for $8 \mathrm{~d}$ separately in tanks and fed known amounts of cultured cells of the dinoflagellate Alexandrium tamarense were held without feeding for an additional $10 \mathrm{~d}$. During the $18 \mathrm{~d}$ study, 3 scallops were removed every $2 \mathrm{~d}$ and the quantity of of each toxin present was analyzed individually. The toxins released into the environmental seawater were recovered and also analyzed. These experiments showed that the individual variation in bivalve toxicity often observed in feeding experiments and field surveys is due to differences in the amounts of dinoflagellate cells ingested by the bivalves and that a portion of the total amount of toxins accumulated in the scallop is released into the environmental water. However, the sum of the amount of toxins in the scallop and that released into the water cannot be explained in terms of the amount supplied by A. tamarense, suggesting that in addition to toxin accumulation from the food chain, another unknown mechanism is involved in toxin accumulation in the scallop. The toxins incorporated into the scallop from $A$. tamarense are considered to undergo metabolism in the scallop through which the toxins are changed to derivatives undetectable by HPLC.
\end{abstract}

KEY WORDS: Scallop · Patinopecten yessoensis · Alexandrium tamarense · Feeding experiment · Paralytic shellfish toxins

\section{INTRODUCTION}

During a bloom of toxic dinoflagellates such as Alexandrium tamarense, paralytic shellfish poisoning (PSP) toxins in the dinoflagellates are transferred to and accumulate in bivalves from the food chain (Schantz 1986), while the amounts of toxins in the bivalves decrease gradually after the disappearance of the dinoflagellates. The decrease in amounts of toxins in the bivalves is considered to be due to either excretion or decomposition, or both, of the toxins in the bivalves, though there have been few reports on the metabolism of accumulated toxins in bivalves. Shimizu \& Yoshioka

*Corresponding author. E-mail: kodama@kitasato-u.ac.jp
(1981) reported that incubated homogenates of the digestive gland of a toxic specimen of the scallop Placopecten magellanicus had the same total amount of toxins, but the toxin profile changed. These results indicate that it is unlikely that toxins are decomposed in the scallop tissue, suggesting that the decrease in amounts of toxins accumulated in the bivalves is due to excretion of the toxins into the environmental medium. Therefore, it is generally accepted that the amount of toxins accumulated in the bivalves is the difference between the amount of toxins supplied by dinoflagellates from the food chain and the amount excreted from the bivalves.

We conducted a field survey on the toxicity of the scallop Patinopecten yessoensis cultured in Ofunato Bay (Iwate, Japan) in association with a bloom of

(C) Inter-Research 2001 
Alexandrium tamarense, a dinoflagellate known to be a causative agent of PSP (Ogata et al. 1982, Sekiguchi et al. 1989). In the survey, we observed some phenomena that could not be explained on the basis of the food chain mechanism of toxin accumulation in bivalves; that is, the scallop toxicity did not increase in parallel with the abundance of $A$. tamarense. We found that scallop toxicity is low when $A$. tamarense shows maximal abundance, but was highest when the cell density of A. tamarense decreased from the maximal peak. Furthermore, scallop toxicity often increased after the disappearance of A. tamarense. However, it was impossible to examine the amounts of toxins supplied by dinoflagellates and the amounts excreted from the scallop quantitatively in the field survey. Therefore, the phenomena observed in the field survey, which could not be explained in terms of the currently accepted mechanism, could not be elucidated by field data. Although it is important to understand the mechanism by which bivalves become toxic through ingestion of toxic dinoflagellates in order to establish effective countermeasures for PSP problems, there have been few studies on this mechanism.

Previously, we reported that bivalve specimens reared in the same tank and fed cultured Alexandrium tamarense showed marked individual variation in the levels of accumulated toxins, probably because of differences in the extent of ingestion of $A$. tamarense (Sekiguchi et al. 2001). These findings suggest that the phenomena with respect to scallop toxicity in the field survey described might be due to individual variation. In the present study, the mechanism by which the scallop Patinopecten yessoensis becomes toxic through ingestion of $A$. tamarense was investigated in feeding experiments in which known amounts of $A$. tamarense cells were fed to scallops reared individually in separate tanks. The toxins supplied by $A$. tamarense, those accumulated in the scallop and those excreted into the ambient water in these experiments were analyzed.

\section{MATERIALS AND METHODS}

Feeding experiments. The strain of Alexandrium tamarense isolated from Ofunato Bay was cultured as reported previously (Sekiguchi et al. 2001). Nontoxic specimens of the $1 \mathrm{yr}$ old scallop Patinopecten yessoensis (mean $\pm \mathrm{SD}$ : $10 \pm 1.4 \mathrm{~g}$ wet weight of soft tissue, $61.8 \pm 4.7 \mathrm{~mm}$ shell height, $\mathrm{n}=27$ ) were purchased from the culture farm in Kamaishi Bay, Iwate Prefecture, Japan. Twenty-seven specimens were transferred individually to twenty-seven $7 \mathrm{l}$ tanks filled with $5 \mathrm{l}$ of seawater that had been filtered through a membrane filter with a pore size of $0.5 \mu \mathrm{m}$. The specimens were reared with aeration for $5 \mathrm{~d}$ without feeding in order to acclimate them to the rearing conditions of 12.3 to $14.5^{\circ} \mathrm{C}$ under 8 to $10 \mu \mathrm{mol}$ photon $\mathrm{m}^{-2} \mathrm{~s}^{-1}$ (12:12 h lightdark cycle). The water in each tank was changed every day. After acclimation, the specimens were individually transferred to 27 tanks in which $A$. tamarense cells had been mixed with 51 of freshly prepared filtered seawater at a cell density of around 60 cells $\mathrm{ml}^{-1}$. Before transferring the scallop specimens, the number of A. tamarense cells in each tank was determined by direct count under a microscope. Each scallop specimen was reared under the conditions described above. After 24 h, A. tamarense cells in the water were counted under a microscope to determine the number of cells ingested by each specimen. Each specimen was then transferred to 51 of newly prepared filtered seawater containing a known amount of $A$. tamarense cells in another tank and reared in the same way. After a further $24 \mathrm{~h}, 3$ scallop specimens were taken for toxin analysis. The rest of the specimens were subjected to the same experimental treatments. The scallop specimens were fed A. tamarense cells for $8 \mathrm{~d}$ in this manner. After feeding was completed on Day 8, the rest of the specimens were held in seawater without feeding for a further $10 \mathrm{~d}$. Three specimens were taken for toxin analysis every $2 \mathrm{~d}$ throughout the study period. The toxins in the water in which a scallop specimen was reared were analyzed as described below.

Amounts of toxins and toxin components in the Alexandrium tamarense cells and the scallop. PSP toxins detected in the organisms are a mixture of saxitoxin (STX) and its derivatives. The structure of toxin components of Alexandium tamarense and scallops detected in the present study is shown in Fig. 1. The toxin amount of the samples is expressed as nmol,

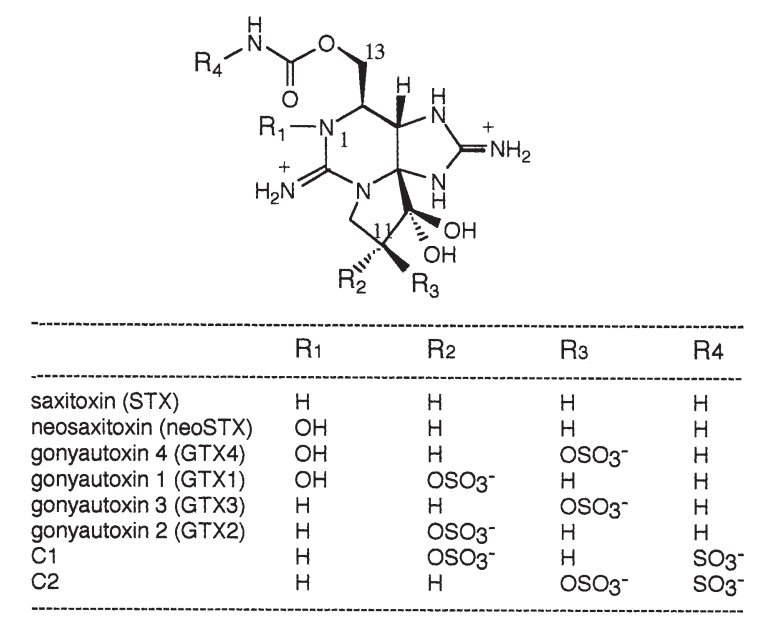

Fig. 1. Chemical structures of paralytic shellfish poisoning toxin components detected in Alexandrium tamarense and scallops 
which is the sum of toxin amount of each component analyzed by HPLC according to Oshima (1995b). Whenever $A$. tamarense cells were fed to a scallop, their toxicity and toxin composition were analyzed by HPLC according to the method of Oshima (1995b). The amounts of toxins supplied to the scallops were calculated every day for each specimen based on the toxin content of the cells and the number of cells ingested by the scallop. The total amount of toxins supplied to each scallop specimen is the sum of the amount of toxins supplied in a period of $8 \mathrm{~d}$. The soft tissues of the scallop specimens were sampled every $2 \mathrm{~d}$ and extracted individually according to the Association of Official Analytical Chemists method (Hollingworth \& Wekell 1990), and the toxins in the extracts were analyzed by HPLC as described above. The accumulated amount of toxins in each scallop was calculated based on the total weight of the tissue.

Amounts and composition of the toxins in rearing seawater. After the seawater in each tank in which scallops were reared had been stirred enough to suspend the fecal pellets, $700 \mathrm{ml}$ of the seawater was taken out. The $\mathrm{pH}$ of the seawater was adjusted to 4 by addition of acetic acid. The seawater samples from each tank thus prepared were kept at $-20^{\circ} \mathrm{C}$ until analysis. After the experiments were completed, water samples obtained on 2 consecutive d were combined, homogenized by sonication for $5 \mathrm{~min}$ on ice and filtered. After adjusting the $\mathrm{pH}$ of the filtrate to 5.5 by addition of diluted ammonium hydroxide, the sample was applied to a $2 \times 5 \mathrm{~cm}$ activated charcoal column for chromatography (Wako Pure Chemical Industries, Osaka, Japan), and the column was washed with $200 \mathrm{ml}$ of distilled water. The toxins adsorbed to the charcoal were then eluted with $200 \mathrm{ml}$ of $25 \%$ ethanol containing $1 \%$ acetic acid. After removal of the ethanol by evaporation, the toxin extract was lyophilized to dryness and then dissolved in $280 \mu$ l of $0.5 \mathrm{M}$ acetic acid. The test solutions thus obtained were analyzed for PSP toxins by HPLC according to the method of Oshima (1995b).

Recovery and stability of PSP toxins dissolved in the seawater. A crude extract of Alexandrium tamarense cells containing $1.3 \mathrm{nmol}$ of PSP toxins was mixed with $1400 \mathrm{ml}$ of filtered seawater. The toxins in the seawater were treated with activated charcoal as described above. The recovered toxins were analyzed by HPLC to determine the percentage recovery. The same mixture of toxins and seawater was left for $24 \mathrm{~h}$ with aeration under the same conditions as those under which the scallops were reared. Toxins in the seawater were also recovered by means of activated charcoal in order to analyze their stability under the rearing conditions. These experiments were carried out in triplicate.

\section{RESULTS AND DISCUSSION}

\section{Toxin content and toxin composition of Alexandrium tamarense fed to scallops}

The toxin content of the Alexandrium tamarense cells fed to the scallops was $87.2 \pm 15.0 \mathrm{fmol} \mathrm{cell}^{-1}$ (mean $\pm \mathrm{SD}, \mathrm{n}=8$ ). The toxin profile of each batch was almost the same: $\mathrm{C} 1+2(56.7 \pm 1.1 \%)$ and gonyautoxin (GTX) $1+4(40.9 \pm 1.0 \%)$, and trace amounts of GTX $2+3$ and neosaxitoxin (neoSTX).

\section{Feeding behavior of scallops in the experiments}

No Alexandrium tamarense cells were observed in the medium after scallop specimens were reared for $24 \mathrm{~h}$, showing that the specimens each ingested all of the A. tamarense cells fed to them. Pseudofeces was not observed. All scallops survived during the experiments.

\section{Toxins released into the rearing water}

Fig. 2 shows the change in amounts of toxins recovered from rearing water in each tank. The average toxin levels as determined through analysis of each of the combined samples from 2 consecutive d (Days 1 and 2, $\mathrm{n}=27$; Days 3 and 4, $\mathrm{n}=24 ; \ldots$ Days 17 and 18, $\mathrm{n}=3$ ) are shown as nmol. The change in the amounts of toxins and the toxin composition in the scallops are also shown for comparison. The toxin levels in the scallops are the average values for 3 specimens sampled on the same day.

The scallop toxin content increased in parallel with the increase in amounts of toxins supplied by the Alexandrium tamarense cells, reaching a maximal of $140 \mathrm{nmol}$ on Day 8, when feeding was stopped. The toxin content of the scallops then decreased gradually during the subsequent period of rearing without feeding to $50 \mathrm{nmol}$ on Day 18, when the experiment was completed. The toxin composition of the scallops changed as observed in a previous study (Sekiguchi et al. 2001); that is, the composition reflected that of A. tamarense just after the feeding, but the proportions of GTX2,3, STX and neoSTX among the total toxin components became larger as the scallops were reared longer.

Considerable amounts of toxins were detected in the rearing water on Day 2. The amounts of toxins in the rearing water tended to increase with the increase in scallop toxin content, and toxins were continuously detected throughout the study period, showing that at least a part of the decrease in amounts of toxins in the 


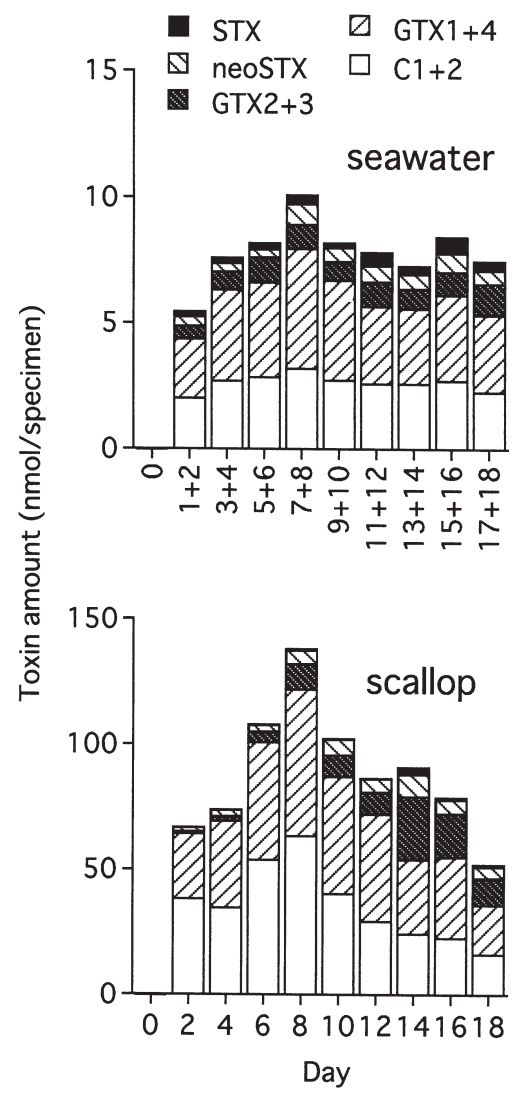

Fig. 2. Change in amounts of PSP toxins recovered from rearing water (upper) and from scallops (lower). The toxin level of rearing water is the average of toxin amounts in all the samples from every 2 consecutive days (Days 1 and 2, $\mathrm{n}=27$; Days 3 and $4, \mathrm{n}=24 ; \ldots$ Days 17 and $18, \mathrm{n}=3$ ), and is expressed as nmol per specimen. The toxin level of scallops is the average (in nmol) of 3 specimens sampled every $2 \mathrm{~d}$. The change in toxin profiles for seawater and scallops is also shown. See

Fig. 1 for abbreviations

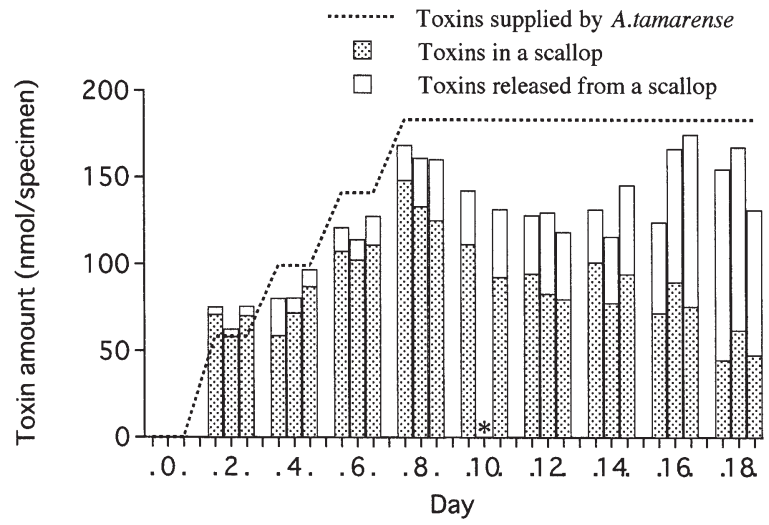

Fig. 3. Change in amounts of PSP toxins accumulated in scallop specimens reared separately in individual tanks. The integrated amounts of toxins released from a single specimen and those supplied to each specimen by feeding Alexandrium tamarense cells are also shown. ${ }^{*}$ The sample was accidentally lost during analysis bivalves is due to the continuous release of toxins from the bivalves. The toxin profile in the rearing water was similar to that in scallops, except that a small amount of STX that was scarcely detected in scallops was always observed in the seawater. This suggests that most of the toxin components except STX are released at a similar rate.

\section{Recovery of PSP toxins from seawater by activated charcoal treatment and the stability of the toxins in seawater}

As determined by HPLC analysis, the recovery of toxins mixed in seawater by activated charcoal treatment was $93.3 \pm 10.4 \%(\mathrm{n}=3)$. During treatment with activated charcoal, transformation of C1,2 to GTX2,3 was observed, probably due to hydrolysis of the N-sulfocarbamoyl sulfate of $\mathrm{C} 1,2$. The relative proportion of GTX1, 4 did not change. Epimerization of $\beta$ form components to $\alpha$ forms due to equilibration was also observed in C1,2, GTX2,3 and GTX1, 4 (Oshima 1995a). On the other hand, the recovery of toxins decreased to $63.8 \pm 6.3 \%(\mathrm{n}=3)$ when the mixture of toxins and seawater was left for $24 \mathrm{~h}$ at $13^{\circ} \mathrm{C}$ with aeration, indicating that part of the total amount of toxins decomposed during incubation.

\section{Accumulation and release of PSP toxins by the scallop}

The change in amounts of PSP toxins accumulated in scallops reared separately in individual tanks is shown in Fig. 3. The integrated amounts of toxins released from a single specimen and those supplied to each specimen by feeding Alexandrium tamarense cells were added (Fig. 3). The amounts of toxins in the sea-

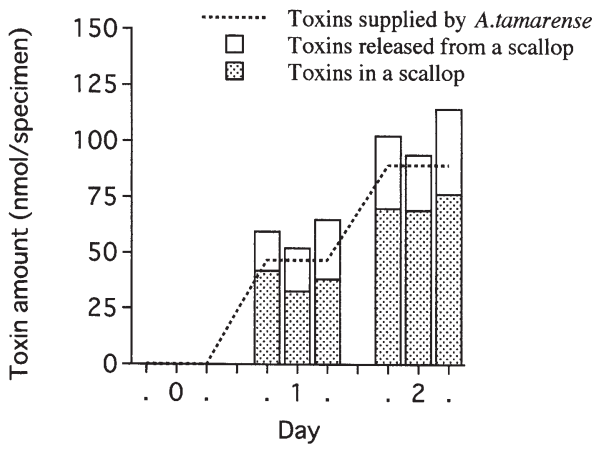

Fig. 4. Change in amounts of PSP toxins accumulated in scallop specimens reared separately in individual tanks for $2 \mathrm{~d}$. Experimental conditions are the same as those in Fig. 3, except that toxins in the rearing seawater and scallops were analyzed every day 
water were corrected based on the percentage recovery of toxins (93.3\%). As described above, the toxins in the seawater partly decomposed after $24 \mathrm{~h}$ with aeration at $13^{\circ} \mathrm{C}$. Since the loss of toxins due to exposure to the seawater was difficult to estimate, in a first attempt it was not taken in to consideration. However, one must keep in mind that the toxin flux in the seawater could probably be underestimated.

The amount of toxins in the scallops increased in parallel with the increase in the amount of Alexandrium tamarense cells fed to the scallops. The amounts of toxins in 3 scallop specimens sampled on the same day were almost the same, showing that scallop specimens that had ingested the same amount of $A$.tamarense cells accumulated the same amount of toxins. Previously, we found that feeding A. tamarense cells to many specimens of various bivalves including scallops, when individuals of each species were reared in the same tank, resulted in marked individual variation in the amount of toxins accumulated in each specimen (Sekiguchi et al. 2001). The results show that the marked individual variation observed in the previous study is due to differences in the feeding behavior of individual specimens in the tank.

Scallop specimens examined on Day 8 had accumulated 68 to $81 \%$ of the toxins supplied, whereas 11 to $19 \%$ were found in the water; 8 to $13 \%$ of the supplied toxins could not be recovered. This level of toxin loss was also observed in the case of specimens examined on Day 4 or 6 . It is noteworthy that the loss of toxins from the closed systems increased when the specimens were reared without feeding. On Days 12 and 14, 21 to $37 \%$ of the supplied toxins disappeared from the experimental system. However, the extent of toxin loss was lower on Days 16 and 18, and most of the supplied toxins were recovered. These findings suggest that the apparent toxin loss during the study was not due to decomposition of the toxins. There may be unknown forms of the toxins that cannot be detected by HPLC. Some of the toxins supplied seem to have been transformed to these unknown forms, and then they changed again into forms detectable by HPLC during the experiments.

The amounts of toxins in 2 out of 3 specimens on Day 2 was about $10 \%$ more than that supplied. The sum of the amount of toxins in the scallop and in the seawater in each of 3 tanks was more than the amount supplied. To confirm this phenomenon, similar experiments were repeated for $2 \mathrm{~d}$ using another 6 scallop specimens. As shown in Fig. 4, the sum of the amount of toxins in the scallop and that in the seawater was always more than the amount supplied, suggesting that toxins may be produced in the scallop. These findings suggest that the toxins detectable by HPLC are formed in the scal- lop from an unknown toxin component(s) present in Alexandrium tamarense.

It is well accepted that PSP toxins in toxic dinoflagellates accumulate in bivalves through the food chain. However, little is known about the metabolism of the toxins in the bivalves, though transformation of toxin components has been reported (Shimizu \& Yoshioka 1981, Sullivan et al. 1983, Oshima et al. 1990, Oshima 1995a). The results of the present study indicate that the metabolism of PSP toxins in the bivalves is more complex than the transformation of toxin components. Recently, we found that toxin components such as GTXs with $O$-sulfate at $\mathrm{C} 11$ react with thiols to form stable conjugates in which the sulfur atom of the thiols binds covalently with the carbon atom at the 11 position of the toxins (Sakamoto et al. 2000, Sato et al. 2000). These conjugates are released as toxins lacking the $O$-sulfate group through reaction with excess thiols. These reactions occur under physiological conditions, suggesting that some of the toxins in Alexandrium tamarense and some of those in the scallop are bound to thiols of biological origin such as glutathione. These conjugates seem to be involved in the metabolism of PSP toxins in bivalves. The unknown toxin component(s) whose existence is suggested in the present study may be these conjugates of toxins with thiols.

Acknowledgments. This work is partly supported by a Grantin-Aid for scientific research from the Ministry of Education, Science, Sports, and Culture in Japan.

\section{LITERATURE CITED}

Hollingworth T, Wekell MM (1990) Paralytic shellfish poison. Biological method. Final action. In: Hellrich K (ed) Official methods of analysis. Association of Official Analytical Chemists, Arlington, p 881-882

Ogata T, Kodama M, Fukuyo Y, Inoue T, Kamiya H, Matsuura F, Sekiguchi K, Watanabe S (1982) The occurrence of Protogonyaulax spp. in Ofunato Bay, in association with the toxification of the scallop Patinopecten yessoensis. Bull Japan Sci Soc Fish 48:563-566

Oshima Y (1995a) Chemical and enzymatic transformation of paralytic shellfish toxins in marine organisms. In: Lassus $P$, Arzul G, Erard-Le Denn E, Gentien P, Marcaillou-Le Baut C (eds) Harmful marine algal blooms. Lavoisier Publishing, Paris, p 475-480

Oshima Y (1995b) Postcolumn derivatization liquid chromatography method for paralytic shellfish toxins. J AOAC Int 78:528-532

Oshima Y, Sugino K, Itakura H, Hirota M, Yasumoto T (1990) Comparative studies on paralytic shellfish toxin profile of dinoflagellates and bivalves. In: Graneli E, Sundstrom B, Edler L, Anderson DM (eds) Toxic marine phytoplankton. Elsevier, New York, p 391-396

Sakamoto S, Sato S, Ogata T, Kodama M (2000) Formation of intermediate conjugates in the reductive transformation of gonyautoxins to saxitoxins by thiol compounds. Fish Sci 66:136-141 
Sato S, Sakai R, Kodama M (2000) Identification of thiolether intermediates in the reductive transformation of gonyautoxins into saxitoxins by thiols. Bioorg Med Chem Lett 10: 1787-1789

Schantz EJ (1986) Chemistry and biology of saxitoxin and related toxins. Annal NY Acad Sci 479:15-23

Sekiguchi K, Inoguchi N, Shimizu M, Saito S, Watanabe S, Ogata T, Kodama M, Fukuyo Y (1989) Occurrence of Protogonyaulax tamarensis and shellfish toxicity in Ofunato Bay from 1980-1986. In: Okaichi T, Anderson DM, Nemoto T (eds) Red tides: biology, environmental

Editorial responsibility: Otto Kinne (Editor), Oldendorf/Luhe, Germany science, and toxicology. Elsevier, New York, p 399-402

Sekiguchi K, Sato S, Kaga S, Ogata T, Kodama M (2001) Accumulation of paralytic shellfish poisoning toxins in bivalves and an ascidian fed on Alexandrium tamarense cells. Fisheries Sci 67:301-305

Shimizu Y, Yoshioka M (1981) Transformation of paralytic shellfish toxins as demonstrated in scallop homogenates. Science 212:547-549

Sullivan JJ, Iwaoka WT, Liston J (1983) Enzymatic transformation of PSP toxins in the littleneck clam (Protothaca staminea). Biochem Biophys Res Commun 114:465-472

Submitted: November 16, 2000; Accepted: February 21, 2001 Proofs received from author(s): September 11, 2001 